\title{
PENGARUH PEMBERIAN Zn TERHADAP KADAR GLUKOSA DARAH DAN KADAR SUPEROKSIDA DISMUTASE PADA TIKUS WISTAR YANG DIINDUKSI STREPTOZOTOCIN
}

\author{
Nadini Kartika ${ }^{1}$, Banundari Rachmawati ${ }^{2}$, Andrew Johan ${ }^{3}$ \\ Program Pacasarjana Magister Ilmu Gizi \\ Universitas Diponegoro \\ J1. Dr. Sutomo No. 16 Randusari, Kota Semarang
}

\begin{abstract}
Diabetes mellitus is a metabolic disease characterized by hyperglycemia. Giving $Z n$ could reduce the reactivity of $R O S$ due to hyperglycemia by increasing SOD status. Zinc ability as an antioxidant also can improve blood glucose level in diabetes mellitus patients. To prove the effect of $\mathrm{Zn}$ with the doses of $3 \mathrm{mg} / \mathrm{kg} \mathrm{BW}$ and $5 \mathrm{mg} / \mathrm{kg} \mathrm{BW}$ for 30 days on blood glucose and SOD levels in Wistar rats induced by STZ. Twenty-eight rats were divided into 4 groups includes $K_{1}$ as a negative control group, $K_{2}$ as a positive control group that is induced by $S T Z 40 \mathrm{mg} / \mathrm{kg} \mathrm{BW,} K_{3}$ as a group that is induced by $S T Z 40 \mathrm{mg} / \mathrm{kg} \mathrm{BW}$ and $\mathrm{Zn}$ were given at a dose of $3 \mathrm{mg} / \mathrm{kg} \mathrm{BW}$ for 30 days orally and $K 4$ as a group that is induced by STZ $40 \mathrm{mg} / \mathrm{kg} \mathrm{BW}$ and $\mathrm{Zn}$ were given at a dose of $5 \mathrm{mg} / \mathrm{kg} \mathrm{BW}$ for 30 days orally. Examination of blood glucose levels used GODPAP methods and SOD levels checked with a colorimeter method. Data were analyzed using Paired T-Tests and Wilcoxon tests. There was a significant decrease in blood glucose levels after administration of $3 \mathrm{mg} / \mathrm{kg} \mathrm{BW} \mathrm{Zn}(p=0,003)$ and $5 \mathrm{mg} / \mathrm{kg} \mathrm{BW}(p=$ $0.018)$ for 30 days in Wistar rats induced by STZ. There was no significant increase in SOD levels after administration of $3 \mathrm{mg} / \mathrm{kg} \mathrm{BW} \mathrm{Zn}(p=0,120)$ but a significant increase in SOD levels after administration of $5 \mathrm{mg} / \mathrm{kg} \mathrm{BW} \mathrm{Zn}$ $(p=0,038)$ for 30 days in Wistar rats induced by STZ. Administration of 5 $\mathrm{mg} / \mathrm{kg} \mathrm{BW}$ Zn for 30 days showed a better effect on blood glucose and SOD levels in Wistar rats induced by STZ when compared with administration of $3 \mathrm{mg} / \mathrm{kg} \mathrm{BW} \mathrm{Zn}$.
\end{abstract}

Keywords: Zn, blood glucose, superoxide dismutase, diabetes

\section{PENDAHULUAN}

Diabetes mellitus merupakan salah satu penyakit metabolik yang ditandai dengan kadar glukosa darah yang tinggi karena gangguan sekresi, aktivitas insulin atau keduanya (Depkes, 2013).(ADA, 2010)Diabetesmellitus menimbulkan angka morbiditas dan mortalitas yang tinggi. Data World Health Organization (WHO) tahun 2008 menjelaskan bahwa angka mortalitas usia 30 hingga 70 tahun yang disebabkan karena penyakit kardiovaskuler dan diabetes mellitus di Indonesia sebanyak 308 per 100.000 jiwa. (WHO, 2008) Menurut
Health Metrics and Evaluation tahun 2014, diabetes mellitus berada di urutan ke- 7 besar penyakit penyebab kematian di Indonesia. (Health Metrics and Evaluation, 2014) Fakta diabetes mellitus diperkuat oleh laporan Riset Kesehatan Dasar (Riskesdas) tahun 2007 bahwa diabetes mellitus $(5,7 \%)$ di Indonesia menempati urutan ke-6 sebagai penyebab kematian (DepKes, 2007).

Gangguan utama pada diabetes mellitus yakni gangguan metabolisme karbohidrat. Asupan karbohidrat dalam kondisi tubuh normal masuk ke hati untuk dikonversi 
menjadi bentuk glukosa. Aliran darah membantu mendistribusikan glukosa ke setiap sel, kemudian disimpan oleh jaringan otot dan hati dalam bentuk glikogen. Pembentukan energi pada proses metabolisme karbohidrat penderita diabetes mellitus terhambat karena glukosa yang tersedia tidak mencukupi kebutuhan. Hormon insulin berperan membantu masuknya glukosa ke dalam sel tubuh, maka gangguan sekresi dan aktivitas insulin dapat mengurangi utilitas glukosa sebagai bahan bakar pembentukan energi. Glukosa yang tidak dapat masuk sel terbawa kembali oleh aliran darah dan berakumulasi dalam pembuluh darah. Stres oksidatif terjadi karena banyaknya glukosa dalam darah yang menimbulkan autooksidasi glukosa dan membentuk reactive oxygen species (ROS) sebagai radikal bebas. Peningkatan stres oksidatif memicu peningkatan progresivitas diabetes mellitus dengan bersifat reaktif menimbulkan kerusakan sel dan jaringan, meningkatkan kejadian perkembangan komplikasi berupa retinopati, nefropati dan neuropati (Vidya, 2011) (Rochette, 2014) (Aouacheri, 2015).

Antioksidan seperti superoksida dismutase (SOD) merupakan enzim yang mampu meredam sifat reaktif ROS dalam tubuh. Aktivitas SOD yang kuat mampu meredam reaktivitas senyawa reaktif pada tubuh sehat, namun produksi ROS yang berlebihan pada diabetes mellitus melemahkan pertahanan SOD dan menimbulkan destruksi sel (Aouacheri, 2015). Penurunan aktivitas enzim antioksidan dapat mengacaukan keseimbangan tubuh akibat reaktivitas ROS. Asupan antioksidan eksogen seperti seng (Zn) mampu memberikan efek positif terhadap tubuh diabetes mellitus sehingga memicu reaksi fisiologis antioksidan untuk menetralisir ROS (Wang, 2011).

Seng turut serta mencegah progresivitas diabetes mellitus. Sebuah penelitian tahun 2013 yang memberikan $\mathrm{Zn}$ dosis $40 \mathrm{mg} /$ hari selama 3 bulan kepada penderita diabetes di Iraq membuktikan ada pengaruh positif $\mathrm{Zn}$ untuk mengendalikan kadar glukosa darah dengan membantu proses sekresi dan aktivitas insulin memfasilitasi masuknya glukosa ke dalam sel (Kang, 2013). Hal tersebut menjelaskan mengenai manfaat $\mathrm{Zn}$ pada diabetes mellitus, namun pendapat lain tahun 2011 menjelaskan pemberian $\mathrm{Zn}$ dosis 240 $\mathrm{mg} /$ hari per oral selama 3 bulan pada penderita diabetes dengan status $\mathrm{Zn}$ awal normal, tidak memberikan dampak yang baik terhadap kerusakan oksidatif dan fungsi vaskuler pada penderita diabetes (Seet, 2011). Kontroversi pendapat mengenai pengaruh $\mathrm{Zn}$ bagi diabetes menjadi alasan perlu dilakukannya penelitian lebih lanjut, mengingat diabetes mellitus selalu disertai dengan defisiensi Zn (Al-Maroof, 2007) (Sun, 2014).

Kemampuan antioksidan $\mathrm{Zn}$ terkait dengan diabetes mellitus seperti meningkatkan status SOD dengan berperan sebagai komponen struktural SOD melindungi sel beta pankreas dari kerusakan yang diakibatkan ROS (Sun, 2009). Seng pada bentuk Copper ZincSOD (CuZn-SOD) mampu meningkatkan aktivitas SOD dengan menjaga kestabilan enzim. Meningkatnya aktivitas SOD berguna bagi pertahanan tubuh dari reaktivitas ROS (DeRubertis, 2004). Peran Zn tidak hanya berpengaruh pada enzim antioksidan, namun Zn juga berpengaruh pada kadar glukosa darah (Song, 2005).

Beberapa penelitian terdahulu menjelaskan pemberian $\mathrm{Zn}$ dengan dosis berbeda bermanfaat bagi kadar glukosa darah tikus hiperglikemia. Penelitian tahun 2014 memberikan $\mathrm{Zn}$ dosis $5 \mathrm{mg} / \mathrm{kg}$ berat badan (BB) pada tikus hiperglikemia selama 3 bulan dan membuktikan bahwa $\mathrm{Zn}$ berperan menstimulasi fosforilasi protein kinase $\mathrm{B}$ dan mengaktifkan metabolisme glukosa sehingga kadar glukosa darah mengalami penurunan. (Sun, 2014) Studi lain tahun 2013 memberikan $\mathrm{Zn}$ dosis 3, 6 dan $9 \mathrm{mg} / \mathrm{kg} \mathrm{BB}$ dengan cara sonde selama 7 minggu juga membuktikan pengaruhnya pada penurunan kadar glukosa darah tikus hiperglikemia (Zhu, 2013). Studi tersebut menggunakan $\mathrm{Zn}$ bentuk zinc threoninate chelate yaitu jenis $\mathrm{Zn}$ yang mengalami proses khelasi. Mengkonsumsi senyawa hasil khelasi dapat menimbulkan efek samping berupa pusing dan mual, selain itu 
senyawa hasil khelasi memiliki keterbatasan karena menghilangkan logam esensial tubuh sehingga apabila diberikan akan memperburuk kondisi kesehatan tikus (Flora, 2010). Bentuk $\mathrm{Zn}$ lain berupa seng sulfat $\left(\mathrm{ZnSO}_{4}\right)$ dosis 45 mg saat ini telah banyak dipasarkan karena seng sulfat tidak menimbulkan efek samping apabila dikonsumsi sesuai dosis anjuran.

Penelitian ini memberikan $\mathrm{Zn}$ dengan 2 dosis terendah yang pernah digunakan pada penelitian sebelumnya yaitu $3 \mathrm{mg} / \mathrm{kg}$ BB dan $5 \mathrm{mg} / \mathrm{kg}$ BB untuk menghindari efek toksisitas apabila kelebihan dosis $\mathrm{Zn}$ pada tikus. Kedua dosis terendah tersebut sebelumnya diketahui bermanfaat untuk mengendalikan kadar glukosa darah tikus hiperglikemia, namun belum diketahui dosis yang lebih baik pengaruhnya pada kadar glukosa darah maupun kadar SOD, sehingga studi ini bertujuan mendalami lebih lanjut mengenai salah satu dosis yang lebih baik pengaruhnya pada kadar glukosa darah dan kadar SOD tikus hiperglikemia. Seng dengan dosis tersebut diharapkan sudah memberikan pengaruh positif, namun tidak menimbulkan menifestasi klinis pada tikus. Pemberian Zn pada tikus dilakukan selama 30 hari karena lama waktu pemberian tersebut pada studi terdahulu sudah memberikan pengaruh pada glukosa darah dan enzim antioksidan (Bolkent, 2009).

Streptozotocin (STZ) merupakan senyawa yang bersifat diabetogenik yang akan diinduksikan pada tikus. Hasil penelitian tahun 2012 membuktikan dosis STZ 40 mg/kg BB yang diinduksikan dapat menyebabkan tikus mengalami hiperglikemia yang ditunjukkan pada pemeriksaan kadar glukosa darah setelah induksi (Rachmawati, 2009).

Berdasarkan latar belakang tersebut maka peneliti akan melakukan studi mengenai pengaruh pemberian Zn terhadap kadarglukosa darah dan kadar SOD pada tikus Wistar yang diinduksi STZ. Seng diberikan secara sonde pada tikus dengan dosis bertingkat $3 \mathrm{mg} / \mathrm{kg}$ $\mathrm{BB}$ dan $5 \mathrm{mg} / \mathrm{kg}$ BB selama 30 hari.

\section{METODE PENEITIAN}

Penelitian ini merupakan jenis penelitian eksperimental laboratorik dengan menggunakan desain penelitian Randomized Pre Post Test Controlled Group Design. Pemeliharaan dan intervensi hewan coba serta pemeriksaan kadar glukosa darah dan kadar SOD dilaksanakan di Laboratorium Penelitian dan Pengujian Terpadu (LPPT) Universitas Gadjah Mada Yogyakarta.

Sampel penelitian menggunakan tikus putih Rattus norvegicus, galur Wistar jantan dewasa berusia 10 minggu. Jumlah tikus tiap kelompok pada hasil perhitungan adalah 6 ekor, lalu ditambah $10 \%$ dari jumlah per kelompok untuk cadangan, sehingga tiap kelompok ditambah 1 ekor tikus. Hewan coba dibagi menjadi 4 kelompok meliputi $\mathrm{K}_{1}$ sebagai kelompok kontrol negatif, $\mathrm{K}_{2}$ sebagai kelompok kontrol positif yaitu diinduksi STZ $40 \mathrm{mg} / \mathrm{kg} \mathrm{BB}, \mathrm{K}_{3}$ sebagai kelompok yang diinduksi STZ $40 \mathrm{mg} / \mathrm{kg}$ BB dan diberi Zn dosis $3 \mathrm{mg} / \mathrm{kg}$ BB selama 30 hari dan $\mathrm{K}_{4}$ sebagai kelompok yang diinduksi STZ dan diberi Zn dosis $5 \mathrm{mg} / \mathrm{kg}$ BB selama 30 hari.

Variabel yang diukur yaitu pemberian Zn, kadar glukosa darah (pemeriksaan menggunakan metode Glucose Oxidase Phenol 4-Aminophenazone (GODPAP)) dan kadar SOD (pemeriksaan menggunakan metode kolorimeter). Pemeriksaan kadar glukosa darah dan kadar SOD dilakukan sebelum perlakuan dan sesudah perlakuan.

Data dianalisis melalui tahap uji normalitas pada masing-masing kelompok menggunakan uji Shapiro-Wilk. Data yang berdistribusi normal dilakukan uji Paired T-Test sedangkan yang berdistribusi tidak normal dilakukan uji Wilcoxon. Data juga dianalisis melalui tahap uji normalitas pada masing-masing waktu pemeriksaan. Data yang berdistribusi normal dilakukan uji One Way Anova sedangkan yang berdistribusi tidak normal dilakukan uji Kruskal Wallis.

\section{HASIL DAN PEMBAHASAN}

\section{Hasil}

\section{a. Karakteristik Hewan Coba}

Penimbangan berat badan tikus dilakukan sebagai pemenuhan kriteria inklusi, selain itu juga dilakukan penimbangan setiap 1 minggu sekali selama pemberian $\mathrm{Zn}$ sebagai acuan 
menentukan banyaknya larutan Zn yang diberikan tiap ekor tikus selama 7 hari. Tujuan pemantauan berat badan tikus dikaitkan dengan kondisi hiperglikemia yaitu mengetahui perubahan berat badan selama induksi STZ dan perberian Zn.
Kondisi hiperglikemia memaksa tubuh menggunakan persediaan lemak, proten dan otot sehingga berdampak pada penurunan berat badan. Perubahan berat badan tikus selama penelitian dapat dilihat pada Tabel 1 berikut ini.

Tabel 1. Berat Badan Tikus

\begin{tabular}{|c|c|c|c|c|c|}
\hline & \multicolumn{4}{|c|}{ Berat Badan (gram) } & \multirow{2}{*}{ Nilai $P^{d}$} \\
\hline & $\mathbf{K}_{1}$ & $\mathbf{K}_{2}$ & $\mathbf{K}_{3}$ & $\mathbf{K}_{4}$ & \\
\hline & $(\overline{\mathrm{x}} \pm \mathrm{SD})$ & $(\overline{\mathrm{x}} \pm \mathrm{SD})$ & $(\overline{\mathrm{x}} \pm \mathrm{SD})$ & $(\overline{\mathrm{x}} \pm \mathrm{SD})$ & \\
\hline $\begin{array}{l}\text { Awal } \\
\text { Penelitian }^{\mathrm{a}}\end{array}$ & $196,30 \pm 17,75$ & $201,05 \pm 8,88$ & $194,45 \pm 10,67$ & $171,09 \pm 3,84$ & 0,0001 \\
\hline $\begin{array}{l}\text { Sebelum } \\
\text { Perlakuan }^{\text {b }}\end{array}$ & $212,24 \pm 18,26$ & $161,48 \pm 13,62$ & $165,35 \pm 16,48$ & $143,17 \pm 5,63$ & 0,0001 \\
\hline $\begin{array}{l}\text { Sesudah } \\
\text { Perlakuan }^{c}\end{array}$ & $274,77 \pm 41,85$ & $194,28 \pm 23,02$ & $173,38 \pm 30,52$ & $149,09 \pm 12,70$ & 0,0001 \\
\hline
\end{tabular}

Keterangan:

$\mathrm{K}_{1}=$ Kelompok kontrol negatif

$\mathrm{K}_{2}=$ Kelompok kontrol positif

$\mathrm{K}_{3}=$ Kelompok diabetes dan diberi $\mathrm{Zn}$ dosis $3 \mathrm{mg} / \mathrm{kg}$ $\mathrm{BB}$

$\mathrm{K}_{4}=$ Kelompok diabetes dan diberi $\mathrm{Zn}$ dosis $5 \mathrm{mg} / \mathrm{kg}$ $\mathrm{BB}$

a. Berat badan awal penelitian (sebelum induksi STZ)

b. Berat badan setelah induksi STZ dan sebelum perlakuan

c. Berat badan sesudah pemberian Zn selama 30 hari

d. Nilai signifikansi uji One Way Anova dan Krukall Wallis Test setiap penimbangan

Berdasarkan Tabel 1 berat badan kelompok $\mathrm{K}_{1}$ (kontrol negatif) awal penelitian, sebelum perlakuan hingga sesudah perlakuan mengalami peningkatan berat badan terus menerus. Berat badan kelompok $\mathrm{K}_{2}$ (kontrol positif), $\mathrm{K}_{3}$ dan $\mathrm{K}_{4}$ justru mengalami penurunan jika dibandingkan antara berat badan awal penelitian dengan berat badan sebelum perlakuan. Berat badan tikus kelompok $\mathrm{K}_{3}$ sesudah perlakuan (pemberian $\mathrm{Zn}$ dosis $3 \mathrm{mg} / \mathrm{kg}$ BB selama 30 hari) meningkat dari 165,35 gram menjadi 173,38 gram. Perubahan yang sama terjadi pada berat badan tikus kelompok $\mathrm{K}_{4}$ (diberikan $\mathrm{Zn}$ dosis $5 \mathrm{mg}$ / kg BB selama 30 hari) dengan adanya penurunan saat sebelum perlakuan dan meningkat setelah pemberian $\mathrm{Zn}$. Perubahan tersebut yaitu dari 143,17 gram menjadi 149,09 gram.

\section{b. Kadar Glukosa Darah Hewan Coba}

Hasil pemeriksaan kadar glukosa darah awal penelitian, sebelum perlakuan dan sesudah perlakuan dapat dilihat pada Tabel berikut ini: 
Tabel 2. Kadar Glukosa Darah Tikus

\begin{tabular}{|c|c|c|c|c|c|}
\hline & \multicolumn{4}{|c|}{ Kadar Glukosa Darah (mg/dl) } & \multirow{2}{*}{ Nilai $\mathbf{P}^{\mathrm{f}}$} \\
\hline & $\mathbf{K}_{1}$ & $\mathbf{K}_{2}$ & $\mathbf{K}_{3}$ & $\mathbf{K}_{4}$ & \\
\hline & $(\overline{\mathrm{x}} \pm \mathrm{SD})$ & $(\overline{\mathrm{x}} \pm \mathrm{SD})$ & $(\overline{\mathrm{x}} \pm \mathrm{SD})$ & $(\overline{\mathrm{x}} \pm \mathrm{SD})$ & \\
\hline $\begin{array}{l}\text { Awal } \\
\text { Penelitian }^{\mathrm{a}}\end{array}$ & $74,34 \pm 6,89$ & $90,67 \pm 8,71$ & $82,17 \pm 7,96$ & $75,14 \pm 8,40$ & 0,016 \\
\hline $\begin{array}{l}\text { Sebelum } \\
\text { Perlakuan }^{\text {b }}\end{array}$ & $65,29 \pm 9,85$ & $273,63 \pm 58,31$ & $315,37 \pm 82,79$ & $293,91 \pm 22,64$ & 0,0001 \\
\hline $\begin{array}{l}\text { Sesudah } \\
\text { Perlakuan }^{c}\end{array}$ & $79,54 \pm 12,30$ & $280,82 \pm 33,58$ & $139,08 \pm 51,66$ & $110,29 \pm 40,87$ & 0,0001 \\
\hline Delta Mean $^{\mathrm{d}}$ & 14,25 & 7,19 & $-176,29$ & $-183,62$ & \\
\hline Nilai Pe & 0,073 & 0,463 & 0,003 & 0,018 & \\
\hline
\end{tabular}

Keterangan:

$\mathrm{K}_{1}=$ Kelompok kontrol negatif (sebelum induksi STZ)

$\mathrm{K}_{2}=$ Kelompok kontrol positif

$\mathrm{K}_{3}=$ Kelompok diabetes dan diberi $\mathrm{Zn}$ dosis $3 \mathrm{mg} / \mathrm{kg}$ $\mathrm{BB}$

$\mathrm{K}_{4}=$ Kelompok diabetes dan diberi $\mathrm{Zn}$ dosis $5 \mathrm{mg} / \mathrm{kg}$ $\mathrm{BB}$

a. Kadar glukosa darah sebelum induksi STZ

b. Kadar glukosa darah setelah induksi STZ dan sebelum perlakuan

c. Kadar glukosa darah sesudah pemberian $\mathrm{Zn}$ selama 30 hari

d. Selisih nilai mean kadar glukosa darah b dan c

e. Nilai signifikansi paired samples test antara b dan $\mathrm{c}$ (nilai $\mathrm{p}<0,05$ artinya sangat bermakna)

f. Nilai signifikansi uji One Way Anova dan Kruskall Wallis Test setiap pemeriksaan.

Berdasarkan Tabel 2, nilai $p$ kelompok $\mathrm{K}_{1}$ dan $\mathrm{K}_{2}$ secara berturut-turut yaitu 0,073 dan $0,463(\mathrm{p}>0,05)$ yang artinya tidak ada perbedaan bermakna pada kadar glukosa darah sebelum dan sesudah perlakuan. Tidak ada perbedaan pada kedua kelompok tersebut karena selama 30 hari tidak dilakukan apapun pada kelompok kontrol negatif dan kontrol positif sehingga kadar glukosa sebelum perlakuan dengan sesudah perlakuan tidak banyak perubahan. Sedangkan nilai p kelompok perlakuan $\mathrm{K}_{3}$ dan $\mathrm{K}_{4}$ secara berturut-turut yaitu 0,003 dan 0,018 (p < $0,05)$ menunjukkan bahwa ada perbedaan yang bermakna antara kadar glukosa sebelum perlakuan dengan kadar glukosa sesudah perlakuan pada kelompok tikus yang diberi $\mathrm{Zn}$ dosis $3 \mathrm{mg} / \mathrm{kg}$ BB dan kelompok tikus yang diberi $\mathrm{Zn}$ dosis 5 $\mathrm{mg} / \mathrm{kg}$ BB selama 30 hari.

\section{c. Kadar Superoksida Dismutase Hewan Coba}

Hasil pemeriksaan kadar SOD sebelum dan sesudah perlakuan dapat dilihat pada Tabel berikut

Tabel 3. Kadar Superoksida Dismutase Tikus Setelah Induksi

\begin{tabular}{|c|c|c|c|c|c|}
\hline & \multicolumn{4}{|c|}{ Kadar SOD (unit/ml) } & \multirow{2}{*}{ Nilai $p^{\mathrm{e}}$} \\
\hline & $\mathbf{K}_{1}$ & $\mathbf{K}_{2}$ & $\mathbf{K}_{3}$ & $\mathbf{K}_{4}$ & \\
\hline & $(\overline{\mathrm{x}} \pm \mathrm{SD})$ & $(\overline{\mathrm{x}} \pm \mathrm{SD})$ & $(\overline{\mathrm{x}} \pm \mathrm{SD})$ & $(\overline{\mathrm{x}} \pm \mathrm{SD})$ & \\
\hline $\begin{array}{l}\text { Sebelum } \\
\text { Perlakuan }^{\mathrm{a}}\end{array}$ & $37,65 \pm 1,68$ & $41,14 \pm 2,42$ & $33,22 \pm 1,40$ & $22,60 \pm 1,17$ & 0,245 \\
\hline $\begin{array}{l}\text { Sesudah } \\
\text { Perlakuan }^{\text {b }}\end{array}$ & $33,69 \pm 1,54$ & $29,65 \pm 1,87$ & $48,80 \pm 2,34$ & $40,25 \pm 2,38$ & 0,405 \\
\hline Delta mean ${ }^{\mathrm{c}}$ & $-3,96$ & $-11,49$ & 15,58 & 17,65 & \\
\hline Nilai $\mathrm{P}^{\mathrm{d}}$ & 0,409 & 0,072 & 0,120 & 0,038 & \\
\hline
\end{tabular}


Keterangan:

$\mathrm{K}_{1}=$ Kelompok kontrol negatif

$\mathrm{K}_{2}=$ Kelompok kontrol positif

$\mathrm{K}_{3}=$ Kelompok diabetes dan diberi $\mathrm{Zn}$ dosis $3 \mathrm{mg} / \mathrm{kg}$ $\mathrm{BB}$

$\mathrm{K}_{4}=$ Kelompok diabetes dan diberi $\mathrm{Zn}$ dosis $5 \mathrm{mg} / \mathrm{kg}$ $\mathrm{BB}$

a. Kadar SOD setelah induksi STZ dan sebelum perlakuan

b. Kadar SOD sesudah pemberian Zn selama 30 hari

c. Selisih nilai mean kadar SOD a dan b

d. Nilai signifikansi paired samples test antara a dan $\mathrm{b}$ (nilai $\mathrm{p}<0,05$ artinya sangat bermakna)

e. Nilai signifikansi uji One Way Anova setiap pemeriksaan.

Berdasarkan Tabel 3 di atas, hanya nilai $\mathrm{p}$ kelompok $\mathrm{K}_{4}$ yang memiliki perbedaan yang bermakna $(\mathrm{p}<0,05)$ yaitu dengan nilai 0,038 . Ada perbedaan yang bermakna pada nilai $p$ menunjukkan bahwa pemberian $\mathrm{Zn}$ dosis $5 \mathrm{mg} / \mathrm{kg}$ BB berpengaruh terhadap perubahan kadar SOD pada kelompok $\mathrm{K}_{4}$.

\section{Pembahasan}

\section{a. Pengaruh Zn Terhadap Berat Badan Tikus}

Berdasarkan Tabel 3 berat badan kelompok $\mathrm{K}_{1}$ (kontrol negatif) awal penelitian, sebelum perlakuan hingga sesudah perlakuan semakin meningkat karena tubuh tikus sehat tidak mendapatkan perlakuan apapun selama proses penelitian, hanya diberikan pakan dan minum standar serta tikus tidak mengalami tingkat stres tinggi akibat induksi STZ sehingga kondisinya semakin baik.

Berat badan kelompok $\mathrm{K}_{2}$ (kontrol positif), $\mathrm{K}_{3}$ dan $\mathrm{K}_{4}$ mengalami penurunan jika dibandingkan antara berat badan awal penelitian dengan berat badan sebelum perlakuan karena tikus mulai mengalami diabetes setelah di induksi STZ. Induksi STZ yang bersifat diabetogenik mampu menimbulkan kerusakan sel beta pankreas dengan gejala hiperglikemia, poliuria serta nafsu makan dan minum meningkat. Fungsi pankreas mensintesis dan sekresi insulin untuk proses oksidasi glukosa sebagai sumber energi (Sunaryo, 2013; Szkudelski, 2001). Insulin yang seharusnya berperan untuk mensintesis reseptor glukosa sehingga dapat membawa glukosa melintasi membran sel menjadi terhambat. Utilitas glukosa di dalam sel untuk bahan bakar pembentukan energi akan terganggu karena kondisi tersebut. Tubuh kekurangan bahan bakar glukosa dalam proses metabolisme pembentukan energi sehingga tubuh menggunakan simpanan lain berupa lemak, otot dan protein. Apabila hal ini sudah terjadi maka berdampak pada penurunan massa tubuh atau berat badan menyusut.

Tikus hiperglikemia kelompok $\mathrm{K}_{2}$ tidak mendapatkan perlakuan apapun setelah di induksi STZ namun berat badannya justru meningkat (berat badan sesudah perlakuan). Kejadian peningkatan berat badan sesudah induksi STZ tidak sesuai dengan dengan teori sebelumnya (ADA, 2010). Tikus hiperglikemia yang sudah mengalami penurunan berat badan sulit untuk meningkatkannya kembali apabila tanpa terapi apapun. Pankreas sudah mengalami kerusakan dan proses sintesis insulin terganggu sehingga akan sulit untuk menyeimbangkan produksi glukosa oleh hati yang terus menerus. Tubuh akan terus menggunakan simpanan lemak, otot dan protein jika persediaan glukosa dalam sel tidak mencukupi. Peningkatan berat badan bisa dimungkinkan karena adanya kelainan jenis pada tikus kelompok $\mathrm{K}_{2}$ yang tidak diamati dari penelitian ini.

Sesudah perlakuan berat badan tikus kelompok K3 (pemberian Zn dosis $3 \mathrm{mg} / \mathrm{kg}$ BB selama 30 hari) meningkat dari 165,35 gram menjadi 173,38 gram. Peningkatan berat badan sesudah perlakuan tidak lebih baik dari berat badan awal penelitian, namun lebih baik dibandingkan berat badan sebelum perlakuan. Hal ini menandakan adanya 
perbaikan pada tubuh tikus hiperglikemia.

Perubahan yang sama terjadi pada berat badan tikus kelompok K4 (diberikan $\mathrm{Zn}$ dosis $5 \mathrm{mg} / \mathrm{kg}$ BB selama 30 hari) dengan adanya penurunan saat sebelum perlakuan dan meningkat setelah pemberian Zn. Perubahan dari 143,17 gram menjadi 149,09 gram menunjukkan peningkatan namun tidak lebih banyak pengaruhnya dibandingkan perubahan pada kelompok K3 (165,35 gram menjadi 173,38 gram). Dilihat dari peningkatan berat badan, $\mathrm{Zn}$ dosis $3 \mathrm{mg} / \mathrm{kg}$ BB lebih baik diberikan pada tikus hiperglikemia dibandingkan $\mathrm{Zn}$ dosis $5 \mathrm{mg} / \mathrm{kg} \mathrm{BB}$.

\section{b. Pengaruh Zn Terhadap Penurunan Kadar Glukosa Darah Tikus}

Pemberian Zn menyebabkan perubahan terhadap kadar glukosa tikus hiperglikemia. Seng digunakan dalam pembentukan butiran kristal insulin dan saat eksositosis, insulin melepaskan $\mathrm{Zn}$ dalam sirkulasi darah (Al-Maroof, 2006; Quraishi, 2005). Ekskresi Zn yang berlangsung terus menerus mengharuskan peningkatan kebutuhan asupan Zn, hal ini yang mengakibatkan defisiensi $\mathrm{Zn}$ pada diabetes. Abnormalitas metabolisme $\mathrm{Zn}$ menjadi pemicu patogenesis diabetes mellitus dan komplikasi yang menyertainya (Al-Maroof, 2006; Shekokar, 2013). Deplesi Zn melemahkan modifikasi struktural insulin serta menghambat proses sintesis, penyimpanan dan sekresi insulin (Rochette, 2014). Peningkatan asupan $\mathrm{Zn}$ menguntungkan bagi penurunan kadar glukosa darah diabetes. Seng dapat memperbaiki struktur, proses sintesis, penyimpanan dan sekresi insulin sehingga dapat mensintesis transporter glukosa bertranslokasi dari intraseluler menuju membran plasma (Rochette, 2014, Barrett, 2010). Transporter glukosa membantu molekul glukosa melintasi membran sel dan mengurangi penumpukan glukosa di luar sel (Bolkent, 2009).

Berdasarkan Tabel 2, delta mean menunjukkan besarnya perubahan kadar glukosa darah sebelum perlakuan dengan kadar glukosa sesudah perlakuan kelompok $\mathrm{K}_{3}$ dan $\mathrm{K}_{4}$ yakni 176,29 mg/dl $(55,9 \%)$ dan $183,62 \mathrm{mg} / \mathrm{dl}(62,5 \%)$. Angka yang ditunjukkan pada kelompok $\mathrm{K}_{4}$ lebih besar dibandingkan $\mathrm{K}_{3}$ menandakan pengaruh pemberian $\mathrm{Zn}$ dosis $5 \mathrm{mg} /$ kg BB selama 30 hari terhadap kadar glukosa darah lebih baik dibandingkan pemberian $\mathrm{Zn}$ dosis $3 \mathrm{mg} / \mathrm{kg}$ BB selama 30 hari pada tikus hiperglikemia dengan cara sonde. Tubuh normal membutuhkan $\mathrm{Zn}$ sebagai elemen pertahanan tubuh terhadap radikal bebas, terlebih lagi tikus hiperglikemia yang mengalami defisiensi Zn. Tikus hiperglikemia membutuhkan antioksidan seperti $\mathrm{Zn}$ dengan dosis lebih tinggi untuk memperbaiki kerusakan oksidatif akibat reaktivitas radikal bebas. Seng dosis $3 \mathrm{mg} / \mathrm{kg}$ BB yang diberikan untuk tikus hiperglikemia sudah cukup memperbaiki kadar glukosa darah namun belum cukup banyak perubahannya apabila dibandingkan dengan perubahan pada kadar glukosa darah tikus yang diberi $\mathrm{Zn}$ dosis $5 \mathrm{mg} / \mathrm{kg} \mathrm{BB}$.

\section{c. Pengaruh Zn Terhadap Peningkatan Kadar Superoksida Dismutase Tikus}

Berdasarkan Tabel 3, hanya nilai $\mathrm{p}$ kelompok $\mathrm{K}_{4}$ yang memiliki perbedaan yang bermakna $(p<0,05)$ yaitu dengan nilai 0,038 . Ada perbedaan yang bermakna pada nilai $\mathrm{p}$ menunjukkan bahwa pemberian $\mathrm{Zn}$ dosis $5 \mathrm{mg} / \mathrm{kg} \mathrm{BB}$ berpengaruh terhadap perubahan kadar SODpadakelompokK ${ }_{4}$. PengaruhZndosis $5 \mathrm{mg} / \mathrm{kg}$ BB yang signifikan dibuktikan dengan adanya peningkatan kadar SOD sebesar 17,65 unit/ml (78,1\% dari kadar SOD sebelum perlakuan). Peningkatan kadar SOD kelompok $\mathrm{K}_{4}$ tersebut lebih besar dibandingkan kelompok $\mathrm{K}_{3}$ dengan nilai 15,58 unit $/ \mathrm{ml}(46,9 \%$ dari kadar SOD sebelum perlakuan) menunjukkan bahwa pemberian $\mathrm{Zn}$ dosis $5 \mathrm{mg} / \mathrm{kg} \mathrm{BB}$ terhadap kadar SOD tikus hiperglikemia kelompok $\mathrm{K}_{4}$ lebih baik dibandingkan pemberian $\mathrm{Zn}$ dosis $3 \mathrm{mg} / \mathrm{kg}$ BB terhadap 
kadar SOD tikus hiperglikemia kelompok $\mathrm{K}_{3}$.

Selisih perubahan kadar SOD pada kelompok $\mathrm{K}_{1}$ (3,96 unit/ml) dan $\mathrm{K}_{2}$ (11,49 unit/ml) menunjukkan penurunan yang tidak signifikan. Penurunan kadar SOD pada kelompok $\mathrm{K}_{2}$ diakibatkan karena kondisi hiperglikemia pada diabetes memicu aktivasi NF-kB dan menyebabkan pembentukan hidrogen peroksida serta mengaktivasi PKC. (Valle, 2005) (Giacco, 2010) Proses seluler ini menimbulkan stres oksidatif yaitu suatu kondisi akibat ketidakseimbangan antara produksi ROS (sebagai oksidan) dan status antioksidan. (Aouacheri, 2015) (Winarsi, 2012) Pertahanan antioksidan SOD tidak sebanding dengan produksi ROS yang terus menerus pada diabetes sehingga kadar SOD menurun. Sedangkan penurunan SOD kelompok $\mathrm{K}_{1}$ dapat dikaitkan dengan berat badan tikus yang semakin meningkat. Tikus kelompok $\mathrm{K}_{1}$ sebagai kontrol negatif tidak mendapatkan perlakuan apapun baik induksi STZ maupun pemberian Zn dan hanya diberikan pakan standar dan minum. Semakin hari berat badan tikus meningkat dikhawatirkan mengalami berat badan berlebih. Berat badan berlebih dan obesitas dapat memicu gangguan pada sistem imun tubuh khususnya status antioksidan seperti SOD. Selain itu usia tikus yang semakin bertambah dapat memicu penumpukan radikal bebas pula di dalam tubuh. Proses penuaan menyebabkan fungsi organ tubuh perlahan berkurang. Bertambahnya usia juga menyebabkan kerusakan akibat radikal bebas meningkat dan dalam waktu singkat menyebabkan penurunan kadar SOD.

\section{SIMPULAN DAN SARAN}

Pemberian Zn selama 30 hari dengan dosis $5 \mathrm{mg} / \mathrm{kg}$ BB lebih baik daripada dosis $3 \mathrm{mg} / \mathrm{kg}$ BB terhadap kadar glukosa darah dan kadar SOD pada tikus Wistar yang diinduksi STZ. Saran yang dapat diberikan yaitu diharapkan dapat menelaah lebih lanjut mengenai pemberian Zn pada subjek manusia agar dapat dijadikan bahan pertimbangan kebijakan kesehatan dalam memperbaiki kondisi penderita diabetes mellitus.

\section{DAFTAR PUSTAKA}

ADA. 2010. Diagnosis and Classification of Diabetes Mellitus. Journal Diab Care; 33(1).

ADA. 2010. Position statement: Standards of Medical Care in Diabetes 2010. Suppl.1. Diab Care;33(1):S11-S61.

Al-Maroof, R., Al-Sharbatti, S. 2006. Serum Zinc Levels in Diabetic Patients and Effect of Zinc Supplementation on Glycemic Control of Type 2 Diabetics. Saudi Med J;27(3):344-50.

Aouacheri, O., Saka S., Krim, M., Messaadia, A., Maidi, I. 2015. The Investigation of The Oxidative Stress-Related Parameters in Type 2 Diabetes Mellitus. Can J Diabetes;39:44-9.

Barrett, KE., Barman, SM., Boitano, S., Brooks, HL. 2010. Ganong's Review of Medical Physiology. 23 ed: McGraw-Hill Companies;1-47.

Bolkent, S., Yanardag, R., Mutlu, O. 2009. The Influence of Zinc Supplementation on the Pancreas of Streptozotocin-Diabetic Rats. Dig Dis Sci. 2009;54:2583-7.

DepKes. Riset Kesehatan Dasar (Riskesdas). 2007.

DepKes. Riset Kesehatan Dasar (Riskesdas). 2013.

DeRuberti, FR., Craven, PA., Melhem, MF., Salah, EM. 2004. Attenuation of Renal Injury in $\mathrm{db} / \mathrm{db}$ Mice Overexpressing Superoxide Dismutase. Diabetes;53:762-8. 
Flora, SJS., Pachauri, V. 2010. Chelation in Metal Intoxication. International Journal of Environmental Research and Public Health;7:2745-88.

Giacco, F., Brownlee, M. 2010. Oxidative Stress and Diabetic Complications. Circ Res;107:105870.

Health Metrics and Evaluation 2014: Available from: www.viz.healthmetricsandevaluation. org/gbd-compare/. Diakses pada 3 Maret 2014

Khan, MI., Siddique, KU., Ashfaq, F., Ali, W., Reddy, HD., Mishra, A., 2013. Effect of HighDose Zinc Supplementation with Oral Hypoglicemic Agents on Glicemic Control and Inflammation in Type-2 Diabetic Nephropathy. Journal of Natural Science, Biology and Medicine;4(2):336-40.

Quraishi, I., Collins, S., Pestaner, JP., Harris, T., Bagasra, O. 2005. Role of Zinc and Zinc Transporters in The Molecular Pathogenesis of Diabetes Mellitus. Med Hypotheses; 65:887-92.

Rachmawati, B. 2012. Pengaruh Pemberian Folate terhadap Kadar Homosysteine, Nitric Oxide dan Status Retinopati Diabetic (Studi Eksperimental pada Tikus Sparague Dawley) [Disertasi]. Semarang: Universitas Diponegoro.

Rochette, L., Zeller, M., Cottin, Y., Vergely, C. 2014. Diabetes, Oxidative Stress And Therapeutic Strategies. Biochim Biophys Acta;1840:2709-29.

Seet, RCS., Lee, C-YJ., Lim, ECH., Quek, AML., Huang, H., Huang, SH, et al. 2011. Oral Zinc Supplementation Does Not Improve Oxidative Stress or Vascular Function in Patients with Type 2 Diabetes with Normal Zinc Levels. Atherosclerosis;219:231-9.

Shekokar, PP., Kaundinya, SD. 2013. Study of Serum Zinc in Diabetes Mellitus. IJBAMR;2(8):977-83.

Song, Y., Wang, J., Li, X., Cai, L. 2005. Zinc and The Diabetic Heart. BioMetals;18:325-32.

Sunaryo, H., Siska., Dwitiyanti., Helmi. 2013. Aktivitas Ekstrak Jahe Gajah (Zingiber officinale) dengan Zinc terhadap Kadar Glukosa Darah Mencit yang Diinduksi Streptozotocin dan Pakan Hiperkolesterol. Jurnal Lemlit UHAMKA.

Sun, Q., Dam, RM., Willett, WC. 2009. Prospective Study of Zinc Intake and Risk of Type 2 Diabetes in Women. Diabetes Care;32(4):629-34.

Sun, W., Wang, Y., Miao, X., Wang, Y., Zhang, L., Xin, Y., et al. 2014. Renal Improvement by Zinc in Diabetic Mice is Associated with Glucose Metabolism Signaling Mediated by Metallothionein and Akt, but Not Akt2. Free Radical Bio Med;68:22-34.

Szkudelski, T. 2001. The Mechanism of Alloxan and Streptozotocin Action in B Cells of the Rat Pancreas. Physiol Res;50(536-546).

Valle, L.G., Milian L.C., Toledob, A., Vilar'o, N., T'apanes, R., Otero, MA. 2005. Altered redox status in patients with Diabetes Mellitus type I. Pharmacol Res;51:375-80.

Vidya, D., Shekhar, R., Prabodh, S., Chowdary, NVS., Reddy, MCDMJ. 2011. Oxidative Stress in Diabetic Retinopathy. Journal of Clinical and Diagnostic Research;5(5):994-7.

Wang C, Li S, Shang D-J, Wang X-L, You Z-L, Li H-B. 2011. Antihyperglycemic and Neuroprotective Effects of One Novel Cu-Zn SOD Mimetic. Bioorganic \& Medicinal Chemistry Letters;21:4320-4.

WHO. 2008: Available from: www.who.int. Diakses tanggal 28 Februari 2014 
Winarsi, H., Wijayanti, SPM., Purwanto A. 2012. Aktivitas Enzim Superoksida Dismutase, Katalase, dan Glutation Peroksidase Wanita Penderita Sindrom Metabolik. MKB;44(1):712.

Zhu, K, Nie S, Li C, Huang J, Hu X, Li W, et al, 2013. Antidiabetic and Pancreas-Protective Effects of Zinc Threoninate Chelate in Diabetic Rats may be Associated with Antioxidative Stress Ability. Biol Trace Elem Res;153(1-3):291-8. 